\title{
GYDYTOJŲ IR SLAUGYTOJŲ POŽIŪRIS İ NEPAGEIDAUJAMŲ IVYKIŲ IR NEATITIKČIŲ VALDYMĄ LIETUVOS BENDROJO POBŪDŽIO LIGONINĖSE
}

\author{
Loreta Marmienè \\ Lietuvos sveikatos mokslų universiteto Visuomenès sveikatos fakulteto \\ Sveikatos vadybos katedra \\ Šiaurès pr. 57, LT-49264 Kaunas, Lietuva \\ Telefonas (+370 6) 8466977 \\ Elektroninis paštas loretamarm@gmail.com

\section{Ramunè Kalèdienè} \\ Lietuvos sveikatos mokslų universiteto Visuomenès sveikatos fakulteto \\ Sveikatos vadybos katedra \\ Šiaurès pr. 57, LT-49264 Kaunas, Lietuva \\ Telefonas (+370 37) 327354 \\ Elektroninis paštas ramune.kalediene@lsmuni.lt \\ Pateikta 2015 m. vasario 15 d., parengta spausdinti gegužès 7 d.
}

DOI:10.13165/SPV-15-1-8-02

\section{Santrauka}

Šiame straipsnyje analizuojamas nepageidaujamų ivykių ir neatitikčių valdymas Lietuvos bendrojo pobūdžio ligoninèse. Tyrimo tikslas - jvertinti bendrojo pobūdžio ligoniniu gydytojų ir slaugytoju požiūri i nepageidaujamų ivykiu ir neatitikčiu valdymą. $2014 \mathrm{~m}$. birželio-gruodžio mén. atliktame tyrime taikant anketinès apklausos metoda dalyvavo 1020 asmens sveikatos priežiūros specialistų, dirbančiu bendrojo pobūdžio ligoninèse. Tyrimo duomenimis, 9,9 proc. respondentu nežinojo, kas yra nepageidaujamas ivykis, ir 10,7 proc. - nežinojo, kas yra neatitiktis. Reikšmingai daugiau slaugytoju negu gydytoju žinojo, ka ir kur registruoti, kaip nepageidaujama ivyki ir/ar neatitikti. Dauguma respondentu pripažino, jog registruoti nepageidaujamus ivykius ir neatitiktis naudinga. Šioje veikloje aktyviau dalyvavo vyresnio amžiaus bei daugiau darbo patirties turintys asmens sveikatos priežiūros specialistai. Nors dauguma tyrime dalyvavusiu asmens sveikatos priežiūros specialistu nurode, kad įvykus neatitikčiai siekiama išsiaiškinti jos priežastis, tačiau tik pusé apklaustujų žino tolesnius neatitikties tyrimo veiksmus bei yra informuojami apie koregavimo ir prevencinius veiksmus. 
Reikšminiai žodžiai: nepageidaujami ivvykiai, neatitiktis, pacientu sauga, nepageidaujamu ivvykiu registracija.

\section{İvadas}

Šiuolaikinèje asmens sveikatos priežiūroje iš esmès pakito paslaugų kokybès samprata: vienu svarbiausių komponentų tampa pacientų sauga. Mokslinès literatūros analizė igalina teigti, kad teikiant sveikatos priežiūros paslaugas rizikos išvengti nepavyksta. Nustatyta, kad Europos Sąjungos (ES) šalių ligoninèse 8-12 proc. pacientų patiria nepageidaujamus ịvykius, susijusius su infekcijomis (maždaug 25 proc. nepageidaujamų įvykių), vaistais, medicinos prietaisų gedimais, klaidingai nustatytomis diagnozėmis ir kt. ${ }^{1}$ Siekiant sumažinti nepageidaujamų îvykių ir klaidų tikimybę, svarbu žinoti jų priežastis, pasekmes bei dažnį․

Pasaulio sveikatos organizacija (PSO), Ekonominio bendradarbiavimo ir plètros organizacija, ES ir kitos institucijos atsižvelgdamos ì pacientų saugos užtikrinimo svarbą ragina ES šalių bendradarbiavimą, dalinimąsi žiniomis, patirtimi ir gerąja praktika, kad būtų sumažinta galima žala pacientams. Viena iš pagrindinių pacientų saugos gerinimo priemonių - nepageidaujamų ỉvykių pranešimo ir mokymosi sistemų diegimas. Tokias sistemas turi JAV, Australija, Kanada, 27 ES valstybės narės ${ }^{3}$ ir kt. Atlikta nemažai mokslinių tyrimų apie nepageidaujamų ịvykių dažnị, rūšis ${ }^{4,5}$, registracijos naudąą, ${ }^{6,7}$, sveikatos priežiūros specialistų nuomonę apie nepageidaujamų ivvykių ir neatitikčių registraciją, kliūtis, kurios trukdo, ir motyvus, kas skatina registruoti nepageidaujamus ivykius ir neatitiktis ${ }^{8,9}$.

Conklin, A., et al. Improving Patient Safety in the EU. Assessing the expected effects of three policy areas for future action. [interaktyvus]. RAND Technical Report prepared for the European Commission, 2008 [žiūrèta 2014-11-20]. <http://www.rand.org/pubs/technical_reports/TR596/>.

2 Kaldjian, L. C., et al. Reporting Medical Errors to Improve Patient Safety: A Survey of Physicians in Teaching Hospitals. Archives of Internal Medicine. 2008, 168(1): 40-46.

3 Report from the Commission to the Council on the basis of Member States' reports on the implementation of the Council recommendation (2009/C 151/01) on patient safety, including the prevention and control of healthcare associated infections (COM(2014) 371 final).

4 Shaw, R., et al. Adverse events and near miss reporting in the NHS. Qual Saf Health Care. 2005,14: 279-283.

5 Milch, C. E., et al. Voluntary Electronic Reporting of Medical Errors and Adverse Events: An Analysis of 92,547 Reports from 26 Acute Care Hospitals. Journal of General Internal Medicine. 2006, 21(2): 165-170.

6 Pham, C. J.; Girard, T.; Pornovost, J. P. What to do with healthcare Incident reporting systems. Journal of Public Health Research. 2013, 2: e27.

$7 \quad$ Elliott, P.; Martin, D.; Neville, D. Electronic Clinical Safety Reporting System: A Benefits Evaluation. JMIR Medical Informatics. 2014, 2(1): e12.

8 Braithwaite, J.; Westbrook, M. T; Travaglia, J. F.; Hughes, C. Cultural and associated enablers of, and barriers to, adverse incident reporting. Qual Saf Health Care. 2010, 19(3): 229-233.

9 Pfeiffer, Y.; Briner, M.; Wehner, T.; Manser, T. Motivational antecedents of incident reporting: evidence from a survey of nurses and physicians. Swiss Med Wkly. 2013, 12, 143: w13881. 
Lietuvoje pacientų saugai gerinti buvo vykdoma patvirtinta Sveikatos priežiūros kokybės programa 2005-2010 m. ${ }^{10}$, siekiama igyvendinti Pacientu saugos platformą 2010-2014 m. ${ }^{11}$, parengtas teisès aktas, reglamentuojantis privalomą nepageidaujamų ịvykių, kuriais ịvardijami įvykiai, reakcijos, reiškiniai, aplinkybès, atsiradę dèl veikos, galejusios sukelti ar sukèlusios nepageidaujamą išeiti (rezultatą) pacientui, registraciją ${ }^{12}$, tačiau nesukurta nacionalinè nepageidaujamų ịvykių registravimo sistema ${ }^{13}$, veikia tik kai kurių nepageidaujamų ívykių sričių, susijusių su medicinos prietaisų naudojimu, kraujo ir jo komponentų ruošimu ar transfuzija, vaistinių preparatų naudojimu, nustatyta hospitaline infekcija, su pacientų, darbuotojų, gyventojų radiacine sauga bei radiologinemis avarijomis, su audinių, ląstelių ir organų ịsigijimu (paėmimu), ištyrimu, apdorojimu, laikymu, paskirstymu (transportavimu) ir transplantacija, registracija ${ }^{14} .2013$ m. pradètas vykdyti Europos Sąjungos paramos lèšomis finansuojamas projektas „Visuomenès sveikatos priežiūros kokybės gerinimas, diegiant visuomenès sveikatos technologijų vertinimo sistemą ir nepageidaujamų ịvykių registravimo sistemą", kurio vienas iš strateginių tikslų ịdiegti nepageidaujamų i̇vykių registravimo ir stebėsenos sistemą, siekiant užtikrinti kokybiškų sveikatos priežiūros paslaugų teikimą gyventojams.

Šalyje atliekami moksliniai tyrimai, kuriuose analizuojama sveikatos priežiūros specialistų nuomonè apie nepageidaujamų ịvykių registraciją ${ }^{15},{ }^{16}$, klaidas $^{17}$, tačiau nèra tiksliai žinoma nepageidaujamų ívykių apimtis sveikatos

10 Lietuvos Respublikos sveikatos apsaugos ministro $2004 \mathrm{~m}$. rugsejjo $14 \mathrm{~d}$. Nr. V-642 ìsakymas „Dèl Sveikatos priežiūros kokybès užtikrinimo 2005 -2010 m. programos patvirtinimo“. Valstybès žinios. 2004, Nr. 144-5268.

11 Nacionaline pacientu saugos platforma [interaktyvus]. Vilnius, 2009 [žiūrèta 2014-11-13]. <http:// www.vaspvt.gov.lt/node/135>.

12 Lietuvos Respublikos sveikatos apsaugos ministro 2010 m. gegužès 6 d. ịsakymas Nr. V-401 „Dèl privalomų registruoti nepageidaujamų îvykių sąrašo ir registravimo tvarkos aprašo patvirtinimo“. Valstybès žinios. 2010, Nr. 55-2703.

13 Kanapeckienè, V.; Jurkuvėnas, V. Asmens sveikatos priežiūros specialistų požiūrio į nepageidautinus įvykius ir jų priežastis vertinimas. Visuomenés sveikata. 2010, 4(51): 62-71.

14 Lietuvos Respublikos sveikatos apsaugos ministro 2010 m. gegužès 6 d. ịsakymas Nr. V-401 „Dèl privalomų registruoti nepageidaujamų îvykių sąrašo ir registravimo tvarkos aprašo patvirtinimo", supra note 12

15 Janušonis, V.; Kasap, G. Nepageidautini ịvykiai sveikatos priežiūroje: medikų požiūris i̇ jụ registraciją ir pranešimus išvystytos infrastruktūros daugiaprofilinèse ligoninèse. Sveikatos mokslai. 2012, 22(4): 62-69.

16 Mekšriūnaitė S., Rudaitis K., Valintèlienẻ R. Nepageidaujamų ịvykių registravimo ir mokymosi sistemos diegimas Lietuvos bendrojo pobūdžio ligoninèse: esama padètis ir poreikiai. Visuomenès sveikata. 2015, 1 (68): 40-45.

17 Kutkaitè, S.; Brogienė, D. Vilniaus universiteto vyresniujų medicinos kursų studentų ir vyresniujų gydytojų rezidentų žinios ir nuomonè apie klaidą medicinoje. Visuomenés sveikata. 2013, 1 (60): $67-77$. 
priežiūroje šalies mastu, augantis teisminių ieškinių skaičius bei prašomas žalos sveikatai atlyginti sumos skaudžiai veikia sveikatos apsaugos sistemą.

Siekiant sumažinti nepageidaujamų ìvykių tikimybę svarbu registruoti bei analizuoti ịvykius, kurie nesukèlè jokios žalos. $1998 \mathrm{~m}$. teisès aktais buvo numatyta neatitikčių registracija sveikatos priežiūros įstaigose ${ }^{18}$. Neatitiktis apibrèžiama kaip sveikatos priežiūros įstaigos ar jos darbuotojų veiklos neatitikimas teisès aktais bei ịstaigos vidaus dokumentais nustatytų reikalavimų ${ }^{19}$. Neatitiktys retai pažymimos medicininiuose dokumentuose, nors atsitinka dažniau negu nepageidaujami ívykiai, tačiau jos teikia vertingas pamokas be žalingų nepageidaujamų ỉvykių pasekmių ${ }^{20}$.

Nepageidaujamų ìvykių ir neatitikčių registracija - pagrindas nesèkmių prevencijai. Lietuvoje ši problema sprendžiama nelabai veiksmingu būdu, be grị̌tamojo ryšio, kadangi prevencijai skiriama mažai demesio ${ }^{21}$. Siekiant sumažinti galimą žalą pacientams, itin svarbu teigiamas darbuotojų požiūris i̇ nepageidaujamų îvykių registraciją bei ị jų prevenciją. Kaip teigia mokslininkai, tai priklauso nuo organizacijos kultūros, isstaigos vadovo požiūrio ị nesėkmes, nepageidaujamų įvykių ir neatitikčių registracijos sistemos santykio su išorès aplinka ir tokiu būdu lemia sveikatos priežiūros specialistų elgseną ${ }^{22}$.

Šio straipsnio tikslas - išanalizuoti bendrojo pobūdžio ligoninėse dirbančių gydytojų ir slaugytojų požiūrị i nepageidaujamų ịvykių ir neatitikčių valdymą (ivvykių registraciją, analizę bei pokyčių igyvendinimą).

\section{Tyrimo metodologija}

Tyrimo objektas - asmens sveikatos priežiūros specialistų požiūris i nepageidaujamų ịvykių ir neatitikčių valdymą. Tyrimo imtis - Lietuvos bendrojo pobūdžio ligoninèse dirbantys asmens sveikatos priežiūros specialistai (gydytojai, slaugytojos). Atliktas kiekybinis sociologinis tyrimas, kurio metu anoniminès apklausos būdu apklausta 1020 asmens sveikatos priežiūros specialistų, atsako dažnis 81,6 proc.

\footnotetext{
18 Lietuvos Respublikos sveikatos apsaugos ministro 1998 m. spalio 6 d. įsakymas Nr. 571 „Dèl lokalaus medicininio audito nuostatų“. Valstybès žinios. 1998, Nr. 89-2469.

19 Lietuvos Respublikos sveikatos apsaugos ministro 2008 m. įsakymas balandžio 29 d. Nr. V-338 „Dèl minimalių asmens sveikatos priežiūros paslaugų kokybės reikalavimų aprašo tvirtinimo“. Valstybès žinios. 2008, Nr. 53-1992.

20 Evans, S. M., et al. Attitudes and barriers to incident reporting: a collaborative hospital study. Qual Saf Health Care. 2006, 15: 39-43.

${ }^{21}$ Labanauskas, L. Gynybine medicina ir žalos atlyginimo be kaltès modelis [interaktyvus]. Konferencija MRU „Sveikatos sistemos vystymo perspektyvos“, 2011. [žiūrèta 2014-11-13]. <http://ssvp. mruni.eu/wp-content/uploads/2011/10/Labanauskas_Liutauras.pdf $>$.

22 Janušonis, V.; Kasap G., supra note 15.
} 
Vadovaujantis Lietuvos sveikatos informacijos centro duomenimis, $2012 \mathrm{~m}$. buvo užregistruotos 63 bendrojo pobūdžio ligoninès. Planuojant atlikti apklausą, Lietuvos bendrojo pobūdžio ligoninių vadovams buvo išsiųsti elektroniniai laiškai su kvietimu dalyvauti tyrime. Teigiami atsakymai gauti iš šešiolikos gydymo įstaigų (26,7 proc. iš visų kviestų): 1 universitetinès, 4 respublikos, 4 regiono, 7 rajono ligoninių. Šiose įstaigose tyrimas buvo atliekamas $2014 \mathrm{~m}$. birželio-gruodžio mèn. Apklausą ligoninèse atliko ịstaigos vadovo paskirtas darbuotojas, kurị tyrejjas supažindino su tyrimo tikslais ir gautų duomenų panaudojimu. Respublikos ir regiono lygmens ligoninèse buvo apklausiami asmens sveikatos priežiūros specialistai apklausos atlikimo dieną dirbantys atsitiktinai atrinktuose chirurginio ir vidaus ligų profilio skyriuose. Rajoninèse ligoninėse dèl mažo darbuotojų skaičiaus anketos išdalintos visiems chirurginio ir vidaus ligų profilio skyriuose apklausos atlikimo dieną dirbantiems asmens sveikatos priežiūros specialistams. Kiekvienas klausimynas respondentui buvo pateikiamas su voku, ị kurị buvo prašoma įdèti užpildytą klausimyną ir grąžinti atsakingam darbuotojui. Apklausa atlikta laikantis laisvanoriškumo, anonimiškumo, konfidencialumo bei lygiavertiškumo principų.

Tyrimui atlikti buvo naudotas klausimynas, sudarytas autorių. Klausimyno skalių vidiniam nuoseklumui i̇vertinti buvo skaičiuojamas Cronbacho alfa (Cronbach's alpha) koeficientas, kuris, remiasi atskirų klausimų, sudarančių klausimyną, koreliacija ir ịvertina, ar visi klausimai pakankamai atspindi tiriamąjj dydį bei iggalina patikslinti reikiamų klausimų skaičių. Buvo remtasi tuo, jog kuo Cronbacho alfa koeficientas artimesnis vienetui, tuo teiginių, sudarančiu klausimyną, vidinis nuoseklumas didesnis, kuris gerai sudarytam klausimynui turètų būti didesnis negu $0,70^{23}$. Klausimyno patikimumo koeficientas 0,94 . Taip pat atliktas žvalgomasis tyrimas atsitiktinai pasirinktoje ligoninëje.

Klausimyną sudaro 7 dalys (bendravimo atvirumas, darbas komandoje, skyriaus vadovo vaidmuo, ligoninès vadovybès veiksmai, susiję su pacientų sauga, nepageidaujamų ịvykių ir neatitikčių valdymas, grị̌ztamasis ryšys ir mokymasis, demografinè ir socialinè padètis), iš viso 72 klausimai. Klausimyne pateiktus teiginius prašoma ịvertinti Likerto skaleje nuo 1 - visiškai nesutinku iki 5 visiškai sutinku. Likerto skalès atsakymai buvo sugrupuoti: visiškai nesutinku su nesutinku; nei sutinku, nei nesutinku; sutinku su visiškai sutinku.

Pagal pareigas respondentai pasiskirste taip: skyriaus vedejjai $-4,8$ proc. $(\mathrm{N}=$ 49), gydytojai - $31,3(\mathrm{~N}=319)$, vyresniosios slaugytojos $-58,6$ proc. $(\mathrm{N}=598)$, kita - 1,4 proc. $(\mathrm{N}=14)$. Respondentų atsakymai ị klausimą „Jūsų užimamos pareigos" sugrupuoti taip: skyriaus vedejjai, rezidentai priskirti prie gydytojų, slaugos administratorès, akušerès - priskirtos prie slaugytojų. Respondentų pasiskirstymas pagal pareigas panašus i̇ $2013 \mathrm{~m}$. Lietuvoje esantị slaugytojų,

23 Pukènas, K. Kokybiniu duomenu analizè SPSS programa. Kaunas, 2009. 
tenkančių vienam gydytojui, santykį - 1,8424. Kadangi straipsnyje nagrinejjamas gydytojų ir slaugytojų požiūris, tad anketos, kuriose ị klausimą „Jūsų užimamos pareigos“ buvo pateiktas atsakymas „Kita“, nebuvo analizuojamos. Analizei buvo paliktos 1006 anketos, kurias užpildè 36,6 proc. $(\mathrm{N}=368)$ gydytojų ir 63,4 proc. $(\mathrm{N}=638)$ slaugytojų. Respondentų pasiskirstymas pagal lytị, amžių, patirtị bei ligoninès, kurioje dirba, lygmeni pateiktas 1 lentelèje.

1 lentelè. Respondentų socialiniai ir demografiniai duomenys

\begin{tabular}{|c|c|c|c|c|c|c|c|}
\hline & \multicolumn{4}{|c|}{ Pareigos } & & & \\
\hline & \multicolumn{2}{|c|}{$\begin{array}{l}\text { Gydytojai } \\
(\mathrm{N}=368)\end{array}$} & \multicolumn{2}{|c|}{$\begin{array}{l}\text { Slaugytojos } \\
(\mathrm{N}=638)\end{array}$} & \multicolumn{2}{|c|}{$\begin{array}{c}\text { Iš viso } \\
(\mathrm{N}=1006)\end{array}$} & \\
\hline & $\mathrm{N}$ & $\%$ & $\mathrm{~N}$ & $\%$ & $\mathrm{~N}$ & $\%$ & \\
\hline $\begin{array}{l}\text { Darbo patirtis } \\
\text { pagal specialybę }\end{array}$ & & & & & & & \multirow{7}{*}{$\begin{array}{c}P= \\
0,000\end{array}$} \\
\hline Mažiau nei metai & 24 & 6,5 & 22 & 3,4 & 46 & 4,6 & \\
\hline $1-5 \mathrm{~m}$. & 87 & 23,6 & 47 & 7,4 & 134 & 13,3 & \\
\hline $6-10 \mathrm{~m}$ & 52 & 14,1 & 41 & 6,4 & 93 & 9,2 & \\
\hline $11-15 \mathrm{~m}$. & 33 & 9,0 & 41 & 6,4 & 74 & 7,4 & \\
\hline $16-20 \mathrm{~m}$. & 29 & 7,9 & 109 & 17,1 & 138 & 13,7 & \\
\hline Daugiau nei $21 \mathrm{~m}$. & 143 & 38,9 & 378 & 59,2 & 521 & 51,8 & \\
\hline \multicolumn{7}{|l|}{ Lytis } & \multirow{3}{*}{$\begin{array}{c}\mathrm{P}= \\
0,000\end{array}$} \\
\hline Vyras & 108 & 29,3 & 3 & 0,5 & 111 & 11,0 & \\
\hline Moteris & 260 & 70,7 & 635 & 99,5 & 895 & 89,0 & \\
\hline \multicolumn{7}{|l|}{ Amžius } & \multirow{6}{*}{$\begin{array}{c}\mathrm{P}= \\
0,000\end{array}$} \\
\hline $21-30 \mathrm{~m}$ & 77 & 20,9 & 51 & 8,0 & 128 & 12,7 & \\
\hline $31-40 \mathrm{~m}$. & 83 & 22,6 & 104 & 16,3 & 187 & 18,6 & \\
\hline $41-50 \mathrm{~m}$ & 80 & 21,7 & 261 & 40,9 & 341 & 33,9 & \\
\hline $51-60 \mathrm{~m}$ & 80 & 21,7 & 194 & 30,4 & 274 & 27,2 & \\
\hline Daugiau nei $60 \mathrm{~m}$. & 48 & 13,0 & 28 & 4,4 & 76 & 7,6 & \\
\hline
\end{tabular}

Atsakymai ị klausimus „patirtis pagal specialybę“ buvo sujungti: „mažiau nei metai“, „1-5 m.“ ir „6-10 m.“ - „mažiau nei 10 m.“, „11-15 m.“, „16-21 m.."

24 Lietuvos Respublikos sveikatos apsaugos ministro $2014 \mathrm{~m}$. liepos 15 d. įsakymas Nr. V-810 „Dèl sveikatos sistemos plètros ir ligoninių tinklo konsolidavimo iki $2025 \mathrm{~m}$. plano patvirtinimo“. Teises aktu registras, 2014-07-21, Nr. 2014-10411. 
„11-21 m.“; „daugiau nei 21 m.“ - „daugiau nei 21 m.“, taip pat buvo sugrupuoti respondentų atsakymai į klausimą „Jūsų amžius“: „21 - 30 m.“ ir „31-40m.“ - „2140 m.“; „41-50 m“ - „41-50 m.“”; „51-60“ ir „daugiau nei 60 m.“- „51 ir daugiau m.“

Statistines analizés metodai: Statistinių duomenų analizei panaudota statistinio duomenų analizės paketo SPSS 20,0 versija. Atsakymai $\mathfrak{i}$ klausimus buvo nagrinèti apskaičiuojant dažnius, skirtumai tarp grupių (pagal užimamas pareigas, amžių, patirtị bei ar pranešè apie neatitiktị ir/ar nepageidaujamą ịvykị) buvo vertinami $\chi^{2}$ kriterijumi. Lyginant du santykinius dydžius ir norint nustatyti, ar jų skirtumas reikšmingas, buvo skaičiuojamas z koeficientas. Pasirinktas statistinio reikšmingumo lygmuo, kai $\mathrm{p}<0,05$. Nustatant statistinius-koreliacinius ryšius tarp kintamųjų naudotas statistinio ryšio stiprumą ir kryptị rodantis Spirmeno koreliacijos koeficientas $\rho$. Nepageidaujamo įvykio ir/ar neatitikties registracijos ir požiūrio ị nepageidaujamų ịvykių ir neatitikčių valdymą ryšiui ịvertinti taikyta logistinè regresija.

\section{Tyrimo rezultatai}

Nepageidaujamų i̇vykių ir neatitikčių valdymas apima ịvykių registraciją, analizę, koregavimo ir prevencinių veiksmų atlikimą. Pirmasis žingsnis efektyvaus nepageidaujamų ịvykių valdymo link - asmens sveikatos priežiūros specialistų žinios apie tai, ką reikia registruoti. 10,7 proc. respondentų nežinojo ir 19,6 proc. - abejojo, kas yra neatitiktis bei 9,9 proc. nežinojo, kas yra nepageidaujamas ịvykis. Analizuojant tyrimo dalyvių žinojimą, kur užregistruoti nepageidaujamą ịvyki ar neatitiktį, nustatyta, kad 76,0 proc. respondentu susipažinę su nepageidaujamų i̇vykių ir 71,4 proc. - su neatitikčių registracija. Tyrimo duomenų analizè atskleidè, kad reikšmingai daugiau slaugytojų negu gydytojų žino, kas yra neatitiktis ir nepageidaujamas ịvykis bei reikšmingai daugiau slaugytojų žino, kur užregistruoti nepageidaujamą įvykị $(\mathrm{p}<0,05)$.

Kokius nepageidaujamus įvykius privaloma registruoti, $2010 \mathrm{~m}$. reglamentuota LR sveikatos apsaugos ministro įsakymu „Dèl privalomų registruoti nepageidaujamų Ł̇vykių sąrašo ir jų registravimo tvarkos aprašo patvirtinimo “25. Su teisės aktu, kuris ipareigoja darbuotojus pranešti apie privalomus registruoti nepageidaujamus įvykius, yra susipažinę daugiau nei pusė tyrime dalyvavusių asmens sveikatos priežiūros specialistų, tarp jų reikšmingai daugiau slaugytojų negu gydytojų $(\mathrm{p}=0,01)$.

Iš visų tyrime dalyvavusių apklaustųjų trečdalis nežinojo arba abejojo, kad ìstaigoje yra patvirtinta neatitikčių registravimo sistema. Didesnę dalị susipažinusių su esančia sistema sudarè slaugytojos, negu gydytojai $(\mathrm{p}<0,05)$ (2 lentelè).

25 Lietuvos Respublikos sveikatos apsaugos ministro 2010 m. gegužès 6 d. įsakymas Nr. V-401 „Dèl privalomų registruoti nepageidaujamų ịvykių sąrašo ir registravimo tvarkos aprašo patvirtinimo", supra note ${ }^{12}$. 
2 lentelè. Tyrimo dalyvių žinių apie nepageidaujamų įvykių ir neatitikčių registraciją pasiskirstymas

\begin{tabular}{|c|c|c|c|c|c|c|}
\hline \multirow[b]{2}{*}{ Teiginys } & \multicolumn{3}{|c|}{ Gydytojai \%, (N) } & \multicolumn{3}{|c|}{ Slaugytojos \%, (N) } \\
\hline & $\begin{array}{l}\text { Visiškai } \\
\text { nesutin- } \\
\text { ku/nesu- } \\
\text { tinku }\end{array}$ & $\begin{array}{l}\text { Nei su- } \\
\text { tinku, } \\
\text { nei nesu- } \\
\text { tinku }\end{array}$ & $\begin{array}{l}\text { Sutin- } \\
\text { ku / } \\
\text { visiškai } \\
\text { sutinku }\end{array}$ & $\begin{array}{l}\text { Visiškai } \\
\text { nesutinku } \\
\text { /nesu- } \\
\text { tinku }\end{array}$ & $\begin{array}{l}\text { Nei su- } \\
\text { tinku, } \\
\text { nei nesu- } \\
\text { tinku }\end{array}$ & $\begin{array}{l}\text { Sutin- } \\
\text { ku / } \\
\text { visiškai } \\
\text { sutinku }\end{array}$ \\
\hline $\begin{array}{l}\text { Žinau, ką reikia } \\
\text { žymėti kaip } \\
\text { neatitiktị } \\
(\mathrm{p}=0,000)\end{array}$ & $\begin{array}{l}16,6 \\
(61)\end{array}$ & $\begin{array}{l}17,9 \\
(66)\end{array}$ & $\begin{array}{c}65,5 \\
(241)\end{array}$ & $\begin{array}{c}7,4 \\
(47)\end{array}$ & $\begin{array}{l}20,6 \\
(131)\end{array}$ & $\begin{array}{c}72,1 \\
(459)\end{array}$ \\
\hline $\begin{array}{l}\text { Žinau, ką reikia } \\
\text { žymėti, kaip } \\
\text { nepageidaujamą } \\
\text { ivyki }(p=0,000)\end{array}$ & $\begin{array}{l}15,2 \\
(56)\end{array}$ & $\begin{array}{l}13,0 \\
(48)\end{array}$ & $\begin{array}{c}71,7 \\
(264)\end{array}$ & $\begin{array}{l}6,8 \\
(43)\end{array}$ & $\begin{array}{l}11,3 \\
(72)\end{array}$ & $\begin{array}{c}81,9 \\
(522)\end{array}$ \\
\hline $\begin{array}{l}\text { Žinau, kur } \\
\text { užregistruoti } \\
\text { nepageidaujamą } \\
\text { ivyki }(p=0,000)\end{array}$ & $\begin{array}{l}19,4 \\
(71)\end{array}$ & $\begin{array}{l}16,1 \\
(59)\end{array}$ & $\begin{array}{c}64,5 \\
(236)\end{array}$ & $\begin{array}{l}8,3 \\
(52)\end{array}$ & $\begin{array}{c}9,1 \\
(57)\end{array}$ & $\begin{array}{l}82,7 \\
(520)\end{array}$ \\
\hline $\begin{array}{l}\text { Žinau, kur } \\
\text { užregistruoti } \\
\text { neatitiktị } \\
(\mathrm{p}=0,000)\end{array}$ & $\begin{array}{l}19,6 \\
(72)\end{array}$ & $\begin{array}{l}17,7 \\
(65)\end{array}$ & $\begin{array}{c}62,7 \\
(230)\end{array}$ & $\begin{array}{c}7,4 \\
(47)\end{array}$ & $\begin{array}{c}16,2 \\
(103)\end{array}$ & $\begin{array}{c}76,4 \\
(485)\end{array}$ \\
\hline $\begin{array}{l}\text { Istaigoje yra } \\
\text { patvirtinta } \\
\text { neatitikčių } \\
\text { registravimo } \\
\text { sistema } \\
(\mathrm{p}=0,004)\end{array}$ & $\begin{array}{l}10,4 \\
(38)\end{array}$ & $\begin{array}{l}25,1 \\
(92)\end{array}$ & $\begin{array}{c}64,6 \\
(237)\end{array}$ & $\begin{array}{l}5,2 \\
(33)\end{array}$ & $\begin{array}{c}22,9 \\
(145)\end{array}$ & $\begin{array}{c}71,9 \\
(456)\end{array}$ \\
\hline $\begin{array}{l}\text { Esu susipažinęs } \\
\text { su LR sveikatos } \\
\text { apsaugos min- } \\
\text { istro įsakymu } \\
\text { „Dėl privalomų } \\
\text { registruoti } \\
\text { nepageidaujamų } \\
\text { itvykių sąrašo ir } \\
\text { jų registravimo } \\
\text { tvarkos aprašo } \\
\text { patvirtinimo“ } \\
\text { (p =0,01) }\end{array}$ & $\begin{array}{l}23,4 \\
(86)\end{array}$ & $\begin{array}{l}15,5 \\
(57)\end{array}$ & $\begin{array}{c}61,1 \\
(225)\end{array}$ & $\begin{array}{c}16,0 \\
(101)\end{array}$ & $\begin{array}{l}14,7 \\
(93)\end{array}$ & $\begin{array}{c}69,3 \\
(437)\end{array}$ \\
\hline
\end{tabular}


Analizuojant tyrimo duomenų pasiskirstymą pagal respondentų amžiaus grupes bei darbo patirtį, nustatyta, kad reikšmingai daugiau informuoti, ką ir kur registruoti, kaip nepageidaujamą ịvykị ir neatitiktị vyresni negu $41 \mathrm{~m}$. bei turintys daugiau nei $10 \mathrm{~m}$. darbo patirties asmens sveikatos priežiūros specialistai negu jaunesni nei $40 \mathrm{~m}$. kolegos ( $\mathrm{p}=0,000$ ): 17,4 proc. $21-40 \mathrm{~m}$. amžiaus grupès darbuotojų nežinojo, ką žymèti, kaip nepageidaujamą ịvykị, ir 23,0 proc. tos pačios amžiaus grupès respondentų nežinojo, kur registruoti nepageidaujamą ịvykị.

Tyrimo duomenų analizè parodè, kad asmens sveikatos priežiūros specialistų žinojimas, ką ir kur reikia žymèti kaip neatitiktị, labai stipriai koreliuoja su žinojimu apie nepageidaujamų îvykių registraciją (3 lentelè)

3 lentelè. Sąsajos tarp respondentų žinių apie neatitikčių ir nepageidaujamų ịvykių registraciją (Spirmeno koreliacijos koeficientas)

\begin{tabular}{|c|c|c|c|c|}
\hline & $\begin{array}{c}\text { Vidurkis } \\
\text { (st. nuokrypis) }\end{array}$ & $\begin{array}{c}\text { Žinau, ką } \\
\text { žymèti, kaip } \\
\text { neatitiktí }\end{array}$ & $\begin{array}{l}\text { Žinau, ką žy- } \\
\text { mèti, kaip ne- } \\
\text { pageidaujamą } \\
\text { įvykị }\end{array}$ & $\begin{array}{l}\text { Žinau, kur už- } \\
\text { registruoti ne- } \\
\text { pageidaujamą } \\
\text { ịvykị }\end{array}$ \\
\hline $\begin{array}{l}\text { Žinau, ką žymèti, } \\
\text { kaip neatitiktị }\end{array}$ & $3,78(0,90)$ & & & \\
\hline $\begin{array}{l}\text { Žinau, ką } \\
\text { žymèti, kaip } \\
\text { nepageidaujamą } \\
\text { ìvykí }\end{array}$ & $3,84(0,88)$ & $0,854^{\star *}$ & & \\
\hline $\begin{array}{l}\text { Žinau, kur } \\
\text { užregistruoti } \\
\text { nepageidaujamą } \\
\text { ịvyki }\end{array}$ & $3,82(0,96)$ & $0,779^{* *}$ & $0,806^{\star *}$ & \\
\hline $\begin{array}{l}\text { Žinau, kur } \\
\text { užregistruoti } \\
\text { neatitikti }\end{array}$ & $3,83(0,96)$ & $0,774^{\star *}$ & $0,734^{* *}$ & $0,910^{\star *}$ \\
\hline
\end{tabular}

$* *-p<0,001$

Tik puse apklausoje dalyvavusių asmens sveikatos priežiūros specialistų teigé, kad neatitiktị užregistravęs darbuotojas žino tolesnius neatitikties tyrimo veiksmus. Analizuojant tyrimo duomenis nustatyta, kad po neatitikties registracijos reikšmingai daugiau $(\mathrm{p}=0,001)$ respondentų, kurie turi trumpesnę nei $10 \mathrm{~m}$. darbo patirtị, nežino neatitikčių tyrimo sekos. Taip pat nustatyta tendencija, kad kuo jaunesni tyrimo dalyviai, tuo reikšmingai mažiau žino apie neatitikties tyrimo veiksmus $(\mathrm{p}=0,001)$. 
Tyrimo metu buvo siekiama išsiaiškinti, ar darbuotojas, užregistravęs neatitikti, informuojamas apie koregavimo ir prevencinius veiksmus. Nustatyta, kad tik puse tyrimo dalyvių pritare šiam teiginiui. Pažymètina, kad reikšmingai daugiau slaugytojų negu gydy tojų žino apie tolesnius neatitikties tyrimo veiksmus bei yra informuojami apie koregavimo ir prevencinius veiksmus $(\mathrm{p}=0,001)$.

Tyrimo duomenų analizé atskleidé, kad tyrime dalyvavę asmens sveikatos priežiūros specialistai pripažįsta, jog naudinga registruoti nepageidaujamus ivvykius ( 84,9 proc.) ir neatitiktis (78,1 proc.). Reikšmingai didesnè dalis gydytojų negu slaugytojų pritaria nepageidaujamų îvykių registracijai $(\mathrm{p}<0,05)$.

Analizuojant tyrimo duomenis pagal respondentų amžiaus grupes nustatyta, kad reikšmingai didesnè dalis 21-40 m. amžiaus grupès darbuotojų linkę pritarti neatitikčių registracijos naudai negu 41-50 m. amžiaus grupès dalyvių ( $\mathrm{p}=0,01)$.

Siekiant, kad nepageidaujamas įvykis ar neatitiktis nepasikartotų svarbu nuodugniai išanalizuoti jų priežastis bei pasinaudojus gauta informacija pagerinti pacientų saugą ìstaigoje. Dauguma (73,1 proc.) tyrime dalyvavusių asmens sveikatos priežiūros specialistų nurodè, kad įvykus neatitikčiai siekiama išsiaiškinti jos priežastis. Tyrimo duomenimis, 68 proc. respondentų pritaria, kad nepageidaujamų ịvykių ir neatitikčių analizės metu gautos žinios yra panaudojamos gerinant pacientų saugą.

Tyrimo metu buvo siekiama išsiaiškinti, ar asmens sveikatos priežiūros specialistai kalbasi apie nepageidaujamus įvykius ir neatitiktis. Nustatyta, kad 71,8 proc. respondentų pasitarimų metu atvirai diskutuoja apie nepageidaujamus ịvykius ir 66,9 proc. tyrimo dalyvių teige, kad kalbasi apie neatitiktis.

Daugiau nei du trečdaliai darbuotojų atvirai dalinasi informacija, jeigu kas nors nepasiseke darbe. Analizuojant tyrimo duomenis pagal respondentu užimamas pareigas nustatyta, kad slaugytojos reikšmingai labiau linkusios atvirai pasikalbèti apie nesèkmes negu gydytojai $(\mathrm{p}=0,001)$. Apie nesèkmes darbe reikšmingai dažniau pasidalina vyresni nei $40 \mathrm{~m}$. amžiaus grupès darbuotojai $(\mathrm{p}=0,001)$ taip pat tyrimo dalyviai, turintys daugiau negu $10 \mathrm{~m}$. darbo patirties $(\mathrm{p}=0,001)$.

Tyrimo metu respondentų buvo klausiama, ar esate pranešę apie neatitiktį ir nepageidaujamą ìvykį. Atlikus duomenų analizę nustatyta, kad 21,3 proc. respondentų yra pranešę apie nepageidaujamą įvykị ir 19,2 proc. - apie neatitiktị. Apie nepageidaujamus ịvykius mažiausiai pranešimų padarę 21-40 m. amžiaus darbuotojų lyginant su vyresnio amžiaus asmens sveikatos priežiūros specialistais $(\mathrm{p}=0,001)$.

Analizuojant tyrimo duomenis pagal respondentų patirtị ir nepageidaujamų ivvykių bei neatitikčių registraciją, nustatyta, kad daugiau patirties turintys darbuotojai dažniau pranešè apie neatitiktis ir nepageidaujamus įvykius negu turintys patirties mažiau nei 10 metų $(\mathrm{p}=0,001)$. 
Nepageidaujamus ịvykius ir neatitiktis registravo reikšmingai didesnė dalis tyrime dalyvavusių vadovaujančias pareigas užimančių darbuotojų - skyriaus vedèjai ir vyresniosios slaugos administratorès $(\mathrm{p}<0,01)$. Lyginant užregistruotu nepageidaujamų îvykių ir neatitikčių skaičių tarp gydytojų ir slaugytojų praneštų atvejų statistiškai reikšmingo skirtumo nenustatyta.

Siekiant išsiaiškinti, kokie veiksniai paskatina registruoti nepageidaujamus Ł̇vykius ir neatitiktis, buvo atlikta logistinè regresija. Žinojimas, kur užregistruoti neatitiktị, padidindavo galimybę užregistruoti neatitiktị 2,11 karto. Taip pat statistiškai reikšmingą ịtaką neatitikčių registracijai daro galimybės skyriuje atvirai išsakyti savo nuomonę darbo klausimais bendraujant su slaugytojomis ( $\check{S}$ = $1,83)$ ir ligoninès vadovybės pokyčiu atlikimas po neatitikčių analizès $(\check{S} S=1,77)$.

Žinojimas, ką reikia žymėti, kaip nepageidaujamą ìvykị (ŠS $=4,79)$, grịžtamojo ryšio užtikrinimas apie ịstaigos darbo kokybę ( $\breve{S} S=2,65)$, supratimas, kad naudinga registruoti neatitiktis $(\check{S} S=1,72)$, pasitarimų metu atviros diskusijos apie nepageidaujamus įvykius $(\check{S} S=1,58)$ didino tikimybę, kad bus pranešta apie nepageidaujamą įvykị.

\section{Rezultatų aptarimas}

Nepageidaujamų įvykių pranešimo sistema negali įvertinti, išmatuoti pacientų saugos sveikatos priežiūros ịstaigoje, ji negali būti naudojama siekiant palyginti organizacijas, tačiau nepageidaujamų ívykių registracija naudinga nustatant silpnas vidinès sistemos vietas, dalijantis informacija apie nepageidaujamus įvykius, gerinant pacientų saugos kultūrą ${ }^{26}$. Lietuvoje nuo $2010 \mathrm{~m}$. sveikatos priežiūros įstaigose privaloma registruoti ir pranešti atitinkamoms institucijoms su tam tikra sritimi susijusius nepageidaujamus ịvykius ${ }^{27}$. Asmens sveikatos priežiūros įstaigos taip pat gali papildomai nusistatyti ir registruoti kitus įvykius. Tačiau Lietuvoje nėra atliktų išsamių NI pasireiškimo dažnio ir jų sukeliamų pasekmių tyrimų ${ }^{28}$.

Pirmieji savo nesëkmes darbe pradèjo registruoti JAV, vèliau D. Britanija bei kitos šalys, šiuo metu daugelis pasaulio šalių registruoja nepageidaujamus ìvykius sveikatos sektoriuje. Tačiau vèliau pasirodè pranešimų, kad užregistruotų nepageidaujamų ịvykių skaičius sveikatos priežiūros įstaigose - tai tik ledkalnio viršūnè, daugelis nesèkmių lieka neužregistruota ir neištirta. Pagrindinès neregistravimo priežastys - medicinos darbuotojų laiko stoka registracijai,

26 Pham, C. J.; Girard, T.; Pornovost, J. P., supra note 6.

27 Lietuvos Respublikos sveikatos apsaugos ministro 2010 m. gegužès 6 d. įsakymas Nr. V-401 „Dèl privalomų registruoti nepageidaujamų ịvykių sąrašo ir registravimo tvarkos aprašo patvirtinimo", supra note 12.

28 Paškevičius, L. Kompleksinio požiūrio ị pacientų saugą ir rizikos valdymą sveikatos priežiūros organizacijose paieška. Sveikatos politika ir valdymas. 2014, 1(6): 133-156. 
nežinojimas, ką ir kur registruoti, baimè sulaukti teisminių ieškinių, neigiamo požiūrio iš bendradarbių, įstaigos vadovybès bei pacientų.

Efektyviai nepageidaujamų ìvykių ir neatitikčių registracijai svarbu, kad sveikatos priežiūros personalas žinotų, ką reikia žymèti kaip nepageidaujamą ịvykị ir neatitiktį. Dauguma tyrime dalyvavusių asmens sveikatos priežiūros specialistų žino, ką ir kur registruoti, kaip nepageidaujamą ịvykị ir/ar neatitiktị. Tyrimo duomenų analizè atskleidè, kad 9,9 proc. gydytojų ir slaugytojų nežinojo, ką reikia žymèti kaip nepageidaujamą ịvykị. Panašūs duomenys gauti 2010 m. J. Kanapeckienès, V. Jurkuvėno Lietuvoje atliktame tyrime, kuriame buvo analizuotas ir ambulatorinių asmens sveikatos priežiūros ịstaigų (poliklinikų) darbuotojų požiūris. Tyrejuc duomenimis, kas dešimtas medikas (10,7 proc.) nežinojo, kas yra nepageidaujamas įvykis ${ }^{29}$.

Apžvelgus kitose šalyse atliktas studijas ${ }^{30,31}$, kurios analizuoja sveikatos priežiūros specialistų nuomonę apie nepageidaujamų įvykių ir neatitikčių registraciją ir analizuojant šio tyrimo duomenis, pasitvirtino bendra tendencija: slaugytojos geriau negu gydytojai yra susipažinę, ką ir kur registruoti kaip nepageidaujamą ịvykị. Mokslinès studijos ${ }^{32,33,34}$ atskleidè, kad gydytojai rečiau praneša apie nepageidaujamus ịvykius negu slaugytojos, tačiau šio tyrimo metu nebuvo nustatyta reikšmingas skirtumas užregistruojant nepageidaujamą ịvyki ar neatitiktị tarp gydytojų ir slaugytojų. Tyrimo duomenų analizé atskleidè, kad tokių ívykių daugiau užregistravo skyriaus vedẻjai ir vyresniosios slaugos administratorès.

Šio tyrimo duomenų analizė atskleidè tendenciją, kad kuo vyresni darbuotojai, tuo reikšmingai geriau žino, kur registruoti nepageidaujamus ịvykius. Reiktų nuodugnesnių tyrimų, siekiant nustatyti šio reiškinio priežastis bei galimybes paskatinti jaunesnius darbuotojus aktyviau registruoti nesėkmes.

Kadangi mūsų šalyje nepageidaujamų ịvykių registracija dar tik plètojama, labai svarbu šviesti, mokyti bei skatinti asmens sveikatos priežiūros personalą registruoti ne tik privalomus nepageidaujamus ịvykius, tačiau ir ịvykius, kurie nesukèlè žalos pacientams. Tai yra svarbus saugios kultūros elementas.

Kuriant pacientų saugos kultūrą, pagrindinis akcentas - atviros bendravimo aplinkos kūrimas, t. y. darbuotojai jaučiasi saugūs registruodami bei disku-

\footnotetext{
29 Kanapeckienė, V.; Jurkuvenas, V., supra note 13.

30 Evans, S. M., et al., supra note 19.

31 Wild, E.; Bradley, H. The gap between nurses and residents in a community hospital's error-reporting system. Joint Commission journal on quality and patient safety. 2005, 31(1): 13-20.

32 Rowin, E. J., et al. Does error and adverse event reporting by physicians and nurses differ? Joint Commission journal on quality and patient safety. 2008, 34(9): 537-45.

33 Braitwaite, J.; Westbrook, M.; Travaglia, J. Attitudes toward large scale implementation of an incident reporting system. International Journal for Quality in Health Care. 2008, 20(3): 184-94.

34 Kingston, M. J.; Evans, S. M.; Smith, B. J.; Berry, J. G. Attitudes of doctors and nurses towards incident reporting: a qualitative analysis. Medical Journal of Australia. 2004, 181: 36-9.
} 
tuodami apie nepageidaujamus įvykius ir neatitiktis įstaigoje. Atliktas tyrimas leidžia teigti, kad ligoninėse asmens sveikatos priežiūros specialistai diskutuoja apie nesėkmès, tačiau pažymètina, kad diskusijose daugiau dalyvauja vyresnio amžiaus darbuotojai. Sẻkmingam mokymuisi iš ịvykusių nepageidaujamų Ł̇vykių ir neatitikčių, svarbu, kad skyrių vadovai pasidalintų pranešimais su skyriaus gydytojais bei slaugytojomis, dar geriau su visu įstaigos personalu ${ }^{35}$. Tyrimo metu nustatyta, kad ligoninėse darbuotojai informuojami apie įvykusius nepageidaujamus ịvykius ir neatitiktis.

Mokslininkai teigia, kad viena iš pagrindinių nurodomų kliūčių nepageidaujamų i̇vykių ir neatitikčių registracijai bei mokymuisi iš klaidų grižzamojo ryšio stoka ${ }^{36,37,38}$. Asmuo, kuris pranešè apie nepageidaujamą ịvykị ir/ar neatitiktị, turi gauti grịžtamąji ryší. Tokia kokybiška komunikacija, kai pranešejas jaučiasi, kad pranešimo pateikimas vertas jo laiko, kai informuojamas apie priemones, kurių buvo imtasi siekiant išsiaiškinti nepageidaujamą ivvykị, gali užtikrinti geranorišką nepageidaujamų ịvykių ir neatitikčių registraciją ir ateityje $\mathrm{e}^{39,40}$. Atliktas tyrimas leidžia teigti, kad ligoninėse trūksta kokybiško grịžtamojo ryšio darbuotojui, kuris pranešè apie nepageidaujamą ìvykị ar neatitiktį.

Taip pat sunku rasti išeitị, kaip suteikti paramą įtrauktiems darbuotojams bei garantuoti, kad įvykis nepasikartotų ${ }^{41}$. Šiai situacijai pagerinti svarbus saugios kultūros kūrimas, skatinamas užregistruotų nepageidaujamų ịvykių priežasčių identifikavimas ir analizavimas, kurio metu mažiau dèmesio turi būti sutelkiama $\mathfrak{i}$ asmení, o daugiau gilinamasi $\mathfrak{i}$ organizacines aplinkybes, kurioms esant ịvyko ivykis.

35 Baesley, J. W.; Escoto, K. H.; Karsh, B. T. Design elements for primary care medical error reporting system. Wisconsin Medical Journal. 2004, 103: 56-9.

36 Evans, S. M., et al., supra note 19.

37 Turunen, H., et al. Patient safety culture in acute care: a web-based survey of nurse managers' and registered nurses' views in four Finnish hospitals. International Journal of Nursing Practice. 2013, 19(6): 609-617.

38 Harrison, R.; Lawton, R.; Stewart, K. Doctors' experiences of adverse events in secondary care: the professional and personal impact. Journal of Clinical Medicine. 2014, 14(6): 585-90.

39 Braithwaite, J.; Westbrook, M. T; Travaglia, J. F.; Hughes, C., supra note 8.

40 Seven step to patient safety. The full reference guide [interaktyvus]. National patient safety agency, 2004 [žiūrèta 2014-11-13]. < http://www.nrls.npsa.nhs.uk/resources/collections/seven-steps-topatient-safety/>.

${ }_{41}$ Vincent, Ch. Understanding and responding to adverse events. The New England Journal of Medicine. 2003, 13: 348 (11): 1051-1056. 


\section{Išvados}

1. Lietuvos bendrojo pobūdžio ligoninèse laipsniškai plètojama nepageidaujamų ivvykių ir neatitikčiu registracija bei analizė, tačiau dalis asmens sveikatos priežiūros specialistų vis dar nežino, kas yra nepageidaujamas įvykis (9,9 proc. respondentų) ir kas yra neatitiktis (10,7 proc.).

2. Nesékmių registracijos nauda įžvelgia reikšmingai daugiau jaunesnio amžiaus asmens sveikatos priežiūros specialistų, tačiau jie mažiausiai užregistravę nepageidaujamų ìvykių ir neatitikčių bei daugiausia šios amžiaus grupès darbuotojų nežino, ką reikia žymèti kaip nepageidaujamą ịvykị ir neatitiktị. Reikšmingai didesnẻ dalis gydytojų negu slaugytojų pritaria nepageidaujamų îvykių ir neatitikčių registracijos naudai, tačiau jie mažiau susipažinę su nepageidaujamų îvykių ir neatitikčių registracija.

3. Dauguma tyrime dalyvavusių asmens sveikatos priežiūros specialistų patvirtino, jog skyriuose pasitarimų metu diskutuojama apie nepageidaujamus įvykius ir neatitiktis, o tai itin svarbu, kuriant pacientų saugos kultūrą.

\section{Pasiūlymai:}

Stacionarinių sveikatos priežiūros ịstaigų vadovybei :

- siekiant, kad darbuotojai aktyviau dalyvautų nepageidaujamų ịvykių ir neatitikčiu registracijoje, svarbu supažindinti visus asmens sveikatos priežiūros specialistus apie kuriuos pastebètus savo darbe nepageidaujamus ívykius ir neatitiktis reikia pranešti bei skatinti dalyvauti mokymuose, susijusiuose su pacientų sauga;

- plètojant nepageidaujamų įvykių ir neatitikčiu registraciją, skatinti gydytojus aktyviau dalyvauti nepageidaujamų ívykių ir neatitikčių, kurie nesukèlè žalos pacientui, registracijoje;

- siekiant užtikrinti kokybišką grižžtamąji ryši pranešèjui, siūloma sukurti aiškią nepageidaujamų ịvykių ir neatitikčių analizès struktūrą ịstaigoje ir su ja supažindinti visus asmens sveikatos priežiūros specialistus, taip pat įtraukti užregistruotame nepageidaujamame ịvykyje ar neatitiktyje dalyvavusius asmenis ị šių ịvykių analizę;

- norint padidinti informacijos apie nepageidaujamus įvykius ir neatitiktis sklaidą bei skatinant darbuotojus pasimokyti iš užregistruotų įvykių, siūloma organizuoti bent kartą per metus darbuotojų susirinkimus, kuriuose būtų pristatoma nuasmeninta informacija apie įstaigoje užregistruotus nepageidaujamus įvykius, rimto pobūdžio neatitiktis, jų analizę bei priimtus sprendimo būdus. Taip pat informacija būtų galima pasidalinti e. naujienlaiškiais. 


\section{Literatūra}

1. Baesley, J. W.; Escoto, K. H.; Karsh, B. T. Design elements for primary care medical error reporting system. Wisconsin Medical Journal. 2004, 103: 56-59.

2. Braithwaite, J.; Westbrook, M. T; Travaglia, J. F.; Hughes, C. Cultural and associated enablers of, and barriers to, adverse incident reporting. Qual Saf Health Care. 2010,19(3): 229-233.

3. Braitwaite, J.; Westbrook, M.; Travaglia, J. Attitudes toward large scale implementation of an incident reporting system. International Journal for Quality in Health Care. 2008, 20(3): 184-94.

4. Conklin, A, et al. Improving Patient Safety in the EU. Assessing the expected effects of three policy areas for future action [interaktyvus]. RAND Technical Report prepared for the European Commission, 2008 [žiūrèta 2014-11-20]. <http://www.rand.org/ pubs/technical_reports/TR596/>.

5. Elliott, P.; Martin, D.; Neville, D. Electronic Clinical Safety Reporting System: A Benefits Evaluation. JMIR Medical Informatics. 2014, 2(1): e12.

6. Evans, S. M., et al. Attitudes and barriers to incident reporting: a collaborative hospital study. Qual Saf Health Care. 2006, 15: 39-43.

7. Harrison, R.; Lawton, R.; Stewart, K. Doctors' experiences of adverse events in secondary care: the professional and personal impact. Journal of Clinical Medicine. 2014, 14(6): 585-590.

8. Janušonis, V.; Kasap, G. Nepageidautini ịvykiai sveikatos priežiūroje: medikų požiūris ị jų registraciją ir pranešimus išvystytos infrastrukturos daugiaprofilinėse ligoninèse. Sveikatos mokslai. 2012, 22(4): 62-69.

9. Kaldjian, L. C., et al. Reporting Medical Errors to Improve Patient Safety: A Survey of Physicians in Teaching Hospitals. Archives of Internal Medicine. 2008, 168(1): 40-46.

10. Kanapeckienè, V.; Jurkuvènas, V. Asmens sveikatos priežiūros specialistų požiūrio ị nepageidautinus ịvykius ir jų priežastis vertinimas. Visuomenés sveikata. 2010, 4(51): 62-71.

11. Kingston, M. J.; Evans, S. M.; Smith, B. J.; Berry, J. G. Attitudes of doctors and nurses towards incident reporting: a qualitative analysis. Medical Journal of Australia. 2004, 181: 36-39.

12. Kutkaitè, S.; Brogienè, D. Vilniaus universiteto vyresniųjų medicinos kursų studentų ir vyresniųjų gydytojų rezidentų žinios ir nuomonè apie klaidą medicinoje. Visuomenes sveikata. 2013, 1(60): 67-77.

13. Labanauskas, L. Gynybinè medicina ir žalos atlyginimo be kaltés modelis [interaktyvus]. Konferencija MRU „Sveikatos sistemos vystymo perspektyvos“, 2011 [žiūrèta 2014-1113]. <http://ssvp.mruni.eu/wp-content/uploads/2011/10/Labanauskas_Liutauras.pdf>.

14. Lietuvos Respublikos sveikatos apsaugos ministro 1998 m. spalio 6 d. ịsakymas $\mathrm{Nr}$. 571 „Dèl lokalaus medicininio audito nuostatų“. Valstybès žinios. 1998, Nr. 89-2469.

15. Lietuvos Respublikos sveikatos apsaugos ministro $2004 \mathrm{~m}$. rugsèjo 14 d. įsakymas Nr. V-642 „Dèl Sveikatos priežiūros kokybės užtikrinimo 2005-2010 m. programos patvirtinimo“. Valstybès žinios. 2004, Nr. 144-5268.

16. Lietuvos Respublikos sveikatos apsaugos ministro $2008 \mathrm{~m}$. balandžio $29 \mathrm{~d}$. ịsakymas Nr. V-338 „Dèl minimalių asmens sveikatos priežiūros paslaugų kokybės reikalavimų aprašo tvirtinimo“. Valstybès žinios. 2008, Nr. 53-1992. 
17. Lietuvos Respublikos sveikatos apsaugos ministro $2010 \mathrm{~m}$. gegužès 6 d. įsakymas Nr. V-401 „Dẻl privalomų registruoti nepageidaujamų ìvykių sąrašo ir registravimo tvarkos aprašo patvirtinimo“. Valstybès žinios. 2010, Nr. 55-2703.

18. Lietuvos Respublikos sveikatos apsaugos ministro $2014 \mathrm{~m}$. liepos 15 d. įsakymas Nr. V-810 „Dèl sveikatos sistemos plètros ir ligoninių tinklo konsolidavimo iki 2025 m. plano patvirtinimo“. Teisés aktų registras. 2014-07-21, Nr. 2014-10411

19. Mekšriūnaitė S., Rudaitis K., Valintėlienẻ R. Nepageidaujamų ịvykių registravimo ir mokymosi sistemos diegimas Lietuvos bendrojo pobūdžio ligoninèse: esama padètis ir poreikiai. Visuomenés sveikata. 2015, 1 (68): 40-45.

20. Milch, C. E., et al. Voluntary Electronic Reporting of Medical Errors and Adverse Events: An Analysis of 92,547 Reports from 26 Acute Care Hospitals. Journal of General Internal Medicine. 2006, 21(2): 165-170.

21. Nacionaliné pacientu saugos platforma [interaktyvus]. Vilnius, 2009 [žiūrèta 2014-1113]. <http://www.vaspvt.gov.lt/node/135>.

22. Paškevičius, L. Kompleksinio požiūrio ị pacientų saugą ir rizikos valdymą sveikatos priežiūros organizacijose paieška. Sveikatos politika ir valdymas. 2014, 1(6): 133-156.

23. Pfeiffer, Y.; Briner, M.; Wehner, T.; Manser, T. Motivational antecedents of incident reporting: evidence from a survey of nurses and physicians. Swiss Med Wkly.2013, 12; 143: w13881.

24. Pham, C. J.; Girard, T.; Pornovost, J. P. What to do with healthcare Incident reporting systems. Journal of Public Health Research. 2013, 2: e27.

25. Pukenas, K. Kokybiniu duomenu analizé SPSS programa. Kaunas, 2009.

26. Report from the Commission to the Council on the basis of Member States' reports on the implementation of the Council recommendation (2009/C 151/01) on patient safety, including the prevention and control of healthcare associated infections (COM(2014) 371 final).

27. Rowin, E. J., et al. Does error and adverse event reporting by physicians and nurses differ? Joint Commission journal on quality and patient safety. 2008, 34(9): 537-545.

28. Seven step to patient safety. The full reference guide [interaktyvus]. National patient safety agency, 2004 [žiūrèta 2014-11-13]. < http://www.nrls.npsa.nhs.uk/resources/ collections/seven-steps-to-patient-safety/>.

29. Shaw, R., et al. Adverse events and near miss reporting in the NHS. Qual Saf Health Care. 2005, 14: 279-283.

30. Turunen, H., et al. Patient safety culture in acute care: a web-based survey of nurse managers' and registered nurses' views in four Finnish hospitals. International Journal of Nursing Practice. 2013, 19(6): 609-617.

31. Vincent, Ch. Understanding and responding to adverse events. The New England Journal of Medicine. 2003, 13; 348 (11): 1051-1056.

32. Wild, E.; Bradley, H. The gap between nurses and residents in a community hospital's error-reporting system. Joint Commission journal on quality and patient safety. 2005, 31(1): 13-20. 


\title{
Attitudes of Physicians and Nurses towards Adverse Events and Near-Miss Management in General Hospitals of Lithuania
}

\author{
Loreta Marmienė, Ramunè Kalèdienè \\ Lithuanian University of Health Sciences
}

Summary. Adverse events and near-miss management in Lithuanian general hospitals is analyzed in this article. The aim of the paper is to evaluate the attitudes of physicians and nurses towards adverse events and near-miss management. 1020 general hospitals health care professionals took part in the anonymous survey, which was performed during the period of June - December, 2014. The results suggested that $9.9 \%$ of the respondents did not know what adverse event is, and $10.7 \%$ did not know the meaning of near-miss. Nurses compared to physicians knew much more about the process of what and where to register the adverse event or near-miss. Most of the respondents declared that it is useful to register adverse events and near-misses. Older health care professionals with longer work experience were considerably more active in this process. Most of the respondents declared that after the near-miss happens, the efforts are put to examine causes of the event, but only half of them knew further near-miss investigation steps and were instructed about the adjustment and preventive actions.

Keywords: adverse events, near-miss, patient safety, reporting of adverse events.

Loreta Marmienė, Lietuvos sveikatos mokslų universiteto Visuomenès sveikatos fakulteto doktorantè.

Loreta Marmienė, Lithuanian University of Health Sciences, Faculty of Public Health, Doctoral student.

Ramunė Kalėdienė, Lietuvos sveikatos mokslų universiteto Visuomenès sveikatos fakulteto dekanè, Sveikatos vadybos katedros vedeja, profesorè.

Ramunè Kaleddienė, Dean of Faculty of Public Health, Head of the Department of Health Management, Professor at the Lithuanian University of Health Sciences. 